\title{
8.5 ВПлив психоемоційного стану на діяльність працівника
}

У сучасних умовах господарювання ефективній та стабільній діяльності підприємств і організацій України, що працюють в системі менеджменту, перешкоджає численна кількість проблем, серед яких слід виділити психоемоційний стан працівників, які організовують і планують свою діяльність і поведінку в критичних ситуаціях коронавірусу з адекватним реагуванням на дану ситуацію.

Сучасний працівник повинен швидко і безболісно адаптуватися до постійних змін суспільних умов та форм спілкування за умови збереження позитивного внутрішнього психоенергетичного потенціалу й гармонії особистості в умовах непрогнозованої пандемії.

Сьогодні психоемоційні і фізичні навантаження можуть викликати не тільки різні види втоми, а й психологічні стреси, які виникають внаслідок надмірної психічної напруги і зміни поведінки робітника.

Як наслідок цього у робітників виникають тимчасові зрушення в фізіологічному і психологічному стані, які проявляються у вигляді [447]:

- зниженні працездатності і витривалості, що виявляється в збільшенні кількості помилок при виконанні праці;

- помилок при виконанні точних рухів з незначними м'язовими зусиллями;

- зменшенні загальної працездатності і витривалості рухового апарату, що виявляється в збільшенні часу реакцій, сповільненні швидкості робочих реакцій та зменшенні м’язових зусиль;

- не сприйманні працівником позитивних сигналів, що призводить до помилок і аварій.

Ще більшу шкідливість і дезорганізацію в сучасних умовах наносить психологічний стрес, який викликаний збільшенням випадків по захворінню короновірусом та необхідністю обов'язкової вакцинації.

У цих умовах працівник повинен як психологічно, так i фізично мобілізувати себе до трудової діяльності 3 метою подальшого виконання 
трудових завдань та повернення до стабільного функціонального працездатного стану. На це суттєвий вплив мають особисті риси характеру, які у кожної людини $€$ різними. Вони впливають на його професійну діяльність, стосунки з оточуючим середовищем, способи дій тощо.

Відомо, що загальні вимоги до сучасного працівника підприємства визначаються широким спектром його професійних функцій, які передбачають певні професійні інтереси, цінності та ідеали, що визначаються його поглядами, переконаннями і вірою в їх соціальну значущість [448].

В рамках соціально-психологічної функції керівник, наприклад, виступає як неформальний лідер і реалізує функцію управління через взаємовідносини людей в колективі, де серед його соціально-психологічних здібностей доцільно виділити:

- комунікативність як дар спілкування з підлеглими;

• динамізм як готовність і здатність вдосконалювати себе;

- емоційну стійкість як здатність утримувати свій настрій на робочому діловому рівні під час впливу негативних і позитивних подразників, несприятливих умов, стресових ситуацій;

- оптимістичне прогнозування як здатність передбачати позитивні зрушення в характеристиках і діяльності підлеглих.

Ці здібності фактично $є$ передумовою загальної професійної характеристики керівників, в діяльності яких повинні поєднуватися організаційно-економічні, виробничо-технічні та соціально-психологічні аспекти $[449,450]$.

Для того, щоб керівник міг управляти людьми, необхідно вміти знайти підхід як до колективу в цілому, так і до окремої людині в цьому колективі. Індивідуальний підхід буде ефективним тоді, коли керівник буде знати основи психології людини і управління, коли зможе дати характеристику власним психологічним особливостям, його емоціям. 
Психічний стан кожного працівника залежить від глибини усвідомлення обов'язку та відповідальності за виконання своїх професійних обов'язків. Практика показує, що, коли людина глибоко усвідомлює громадянський та суспільний обов'язок, а також відповідальність за справу, тоді у неї виникають позитивні психічні емоції. У свою чергу і почуття обов'язку формується й закріплюється через визначені психічні стани.

Позитивні форми психічних станів виникають при досягненні людиною високого рівня загартованості. Негативні форми найчастіше $є$ результатом недостатньої загартованості або емоційних перенапружень.

Один із найефективніших способів допомоги підлеглим у досягненні поставленої мети полягає у тому, щоб пояснити їм, як емоції, пов'язані зі збудженням, можуть привести до стресу або депресії.

Емоції грають роль регуляторів людського спілкування так як людина від народження підготовлена до спілкування 3 іншими людьми за допомогою емоцій, які протягом усього життя продовжують відігравати найважливішу регулюючу роль у його контактах з оточуючими. Сутність емоцій людини визначають властивості, які характеризують його ставлення до подій, оточуючих людей і себе [450].

Саме проникнення у світ переживань людини допомагає розібратися у конкретній події, що сталася у житті. Розуміння характеру переживань означає розуміння того, як сприймається цією людиною навколишній світ загалом, як цей світ впливає на розвиток і становлення його особистості. Вміння розуміти та враховувати переживання - одна з важливих умов ефективної роботи сучасного керівника. 3'ясувати, як вплинула на людину та чи інші подія, можна лише у тому випадку, якщо вдасться зрозуміти характер ії переживань із цього приводу.

Настрій керівника - мало вивчений психічний феномен, який можна було б не торкатися, якби не гостра необхідність підвищення гнучкості та культури управління підлеглими працівниками. Як правило, настрій пов'язаний із задоволенням чи незадоволенням найбільш значущих життєвих потреб. Якщо навіть зміна настрою відбулася внаслідок, на перший погляд, малозначущої, 
випадкової події, виявляється, що вона якимось чином пов'язана 3 тим, що глибоко торкається особистості. Тому настрій керівника $є$ індикатором його внутрішнього добробуту. Тривалий поганий і пригнічений настрій має бути сигналом для допомоги цій людині.

Один 3 головних напрямків розвитку емоцій керівника - формування здатності їх контролювати та регулювати. Ця здатність, або вміння, полягає не тільки у тому, що здобувається навик зовні не виражати своїх почуттів, а й у тому, що людина вчиться поступово аналізувати їх, а також причини, що їх викликали. Набувається також уміння передбачати ситуації, здатні викликати ті чи інші емоції, i, отже, готуватися до них заздалегідь, а інколи ж на основі передбачення уникати ці ситуації.

Емоційне благополуччя працівника дедалі більше залежить від наступних чинників:

- чи займає працівник гідне місце у колективі;

- чи почувається рівним серед оточуючих;

- чи має авторитет серед працівників.

Для емоційного благополуччя працівника важливе значення має й те, у якому колективі він працює.

Протягом усього життя людини емоції продовжують грати найважливішу регулюючу роль у його контактах 3 оточуючими. За зовнішніми виразними рухами, що супроводжують емоційне переживання (міміка, поза, жест), а також за мовленнєвою інтонацією ми судимо про внутрішні стани, переживання оточуючих і враховуємо їх у своїх вчинках. Характер ділової розмови, розмови 3 близькою людиною, спільної з іншими співробітниками, багато в чому залежить від того, байдужі, доброзичливі, веселі чи сумні співрозмовники.

Емоційність як стійку властивість людини характеризує безліч ознак i особливостей [451].

Відомо, що настрої одних людей нестійкі, швидко змінюються, в інших переживання сильні та тривалі. Порівняння кількох співробітників допомагає розкрити і такі головні відмінності в їхній емоційності, як якість переважаючих 
у них емоцій. У зовні однакових ситуаціях одні люди бувають оптимістичні, безтурботні, інші схильні до смутку, третім властиві дратівливість, гнівні спалахи, четверті - боязкі, тривожні.

Керівники також бувають різні, одні - доброзичливі, вміють співпереживати, нетерпимі до несправедливості, інші байдужі до чужих радощів та прикростей, треті можуть і зловтішатися. Ці останні риси пов'язані 3 моральними особливостями людини і відносяться до змістовних емоційних властивостей.

Якщо керівник схильний до позитивних емоцій, має характерне сприйняття навколишньої дійсності, єднання з усім світом, у тому числі, злагоду із самим собою, впевненість у собі, пристосованість до життя, тоді він емоційно стійкий, не губиться у важких ситуаціях, і результати праці за таких умов не погіршуються. Керівник активний, бадьорий, а негативні емоції в нього нетривалі, він має високу самооцінку та саморегуляцію діяльності.

Сьогодні люди схильні до переживання негативних емоцій типу страху, тривоги, смутку, у них не з'являється почуття повної внутрішньої гармонії, злиття зі світом. Із цим пов'язане почуття внутрішньої напруженості. Негативні емоції, особливо тривожність, пов'язані, насамперед, із невдачами у спілкуванні. Тому таким людям властиво відокремлення, приховування від оточуючих своїх думок та почуттів. Разом з тим вони відчувають гостру потребу виговоритися, знайти в оточуючих підтримку. Такі люди, з одного боку, уникають широких контактів, соромляться у незнайомій компанії, але, з іншого боку, виявляють активність та ініціативу у виборі партнерів вузького, емоційно комфортного кола спілкування. Як і для людей позитивно емоційного складу, спілкування для них $\epsilon$ нагальною потребою і невичерпним джерелом позитивних емоцій.

Досвід переживання негативних емоцій у людей негативно емоційного складу сприяє розвитку здатності до самоаналізу, а також до детального аналізу подій, умов діяльності, способів її виконання та своїх можливостей. Проте це притаманно до звичних умов, де заздалегідь можна все передбачити, підготуватися, підстрахуватися. Несподівана зміна умов, а тим більше важкі 
ситуації, що зараз пов'язані 3 пандемією, призводять до порушення налагоджених способів діяльності та погіршення результатів, що досягаються.

Люди, схильні до негативних емоцій, мають занижену самооцінку. Незадоволеність результатами діяльності є тим внутрішнім двигуном, який постійно спонукає їх до самовдосконалення. Діяльність є областю, де люди негативно емоційного складу, мають можливість зменшити негативні емоції за рахунок забезпечення хороших результатів шляхом попередньої підготовки. Люди, схильні до гніву, високо критичні стосовно оточуючих, їм властива потреба у перевазі, висока самооцінка, підвищені претензії. Це призводить до появи почуття невпевненості, тривожності, внутрішньої напруженості. Якщо прагнення переваги не вдається задовольнити, виникає ворожість, підозрілість. Схильність до гніву поєднується з відсутністю навички детально аналізувати події та об'єкти.

Змістовні особливості емоцій формуються під впливом оточуючого середовища. Динамічні та якісні риси емоційності не визначають того, чи буде людина емоційно чуйною, чуйною до смутку і радощів близьких, чи будуть їх емоційні відгуки на події навколишнього життя мати міцний моральний початок. Вочевидь, що легше сформувати здатність до співпереживання до тих людей, у яких в арсеналі їх емоцій гнів не $є$ домінуючим. Таким чином, емоційна вразливість є сприятливою основою для формування чуйності, доброзичливості, ніж флегматичність.

Найефективніший метод навчити людей контролювати свої емоції, стрес і тривожність - розвивати в них упевненість у власних силах. Із цією метою використовують створення позитивного середовища та виховання конструктивного ставлення до помилок і невдач. Ефективним підходом до посилення впевненості у власних силах $є$ створення позитивного оточуючого середовища, яке впливає на емоційний стан працівника.

Останнім часом все більший вплив на виникнення аварійних і шкідливих ситуацій у виробництві спричиняють психофізіологічні умови праці, які змінюють функціональний стан організму і психологічні властивості людини. 
Характер роботи, наприклад, нервово-емоційні та розумові перевантаження, напруженість здорових i слухових аналізаторів приводять до нервової перевтоми, яка послабляє психіку, притупляє увагу i пильність, порушує сприйняття того, що відбувається, знижує аналіз змін обставин і дій. Це в подальшому підвищує фізичну та моральну втому, які, в першу чергу, впливають саме на психіку людини. Тобто, людський фактор, а саме його моральносуб'єктивні характеристики охоплюють емоційні та вольові якості, темперамент, смаки, уподобання, які визначають поведінку людини в сфері виробництва та життедіяльності. Виходячи з цього, стан психічної готовності людини до праці повинен включати такі компоненти:

• оптимальний рівень емоційного збудження;

- тверезу впевненість в своїх силах;

- здатність управляти своїми діями та особистою поведінкою в екстремальних ситуаціях;

- високу стійкість до перешкод по відношенню до несприятливих зовнішніх та внутрішніх впливів;

- прагнення до кінця боротися за досягнення кращого результату.

Для того, щоб відновитися емоційно, фізично і психологічно, та повернутися до звичної працездатності у всіх сферах життя, потрібен час [447].

Сьогодні керівництво підприємств повинне також пам'ятати, що нормальні умови праці $\epsilon$ чинником підвищення продуктивності та працездатності праці й досягаються як організаційно-технічними заходами, так і факторами, що впливають на фізіологічний стан організму робітника, так і на його психічні процеси, які включають соціально-психологічний клімат в колективі, житлово-побутові умови, моральні й матеріальні стимули тощо.

Конкретні виробничі умови праці робітників визначаються сполученням різних психофізіологічних, санітарно-гігієнічних факторів, які впливають на реакцію організму, рівень комфортності його праці. Так, шкідливі фактори можуть привести до травм, чи різкого погіршення здоров'я та стійкого зниження працездатності. Важкість праці впливає в основному на опорно-руховий апарат, 
а також серцево-судину систему та органи дихання. Напруженість праці переважно впливає на центральну нервову систему, Втома знижує працездатність людини, яка, в свою чергу, забезпечується фізіологічними чинниками трудової діяльності людини протягом визначеного періоду часу.

Кожному виду трудової діяльності відповідають визначені фізіологічні, психофізіологічні і психологічні якості людини, але треба пам'ятати, що тільки при комплексній відповідності властивостей людини особливостям конкретної трудової діяльності можлива ефективна праця.

Тому сучасний керівник повинен неформально, глибоко опанувати наукові засади управління. Він повинен знати дані психології та використовувати їх у своїй практиці. Головна мета виховання емоцій - це формування позитивного ставлення до життя, що не виключає виховання адекватних негативно емоційних відгуків на події сьогоднішнього дня, що заслуговують на негативні відносини. Кожен керівник колективу має бути емоційно чуйним. Уміння співчувати, співпереживати, розуміти іншу людину формується в умовах, що постійно дають зразки моральної поведінки. Слід підкреслити цінність таких властивостей, як оптимізм, життєрадісність, емоційна стійкість, тому успіх всього колективу залежатиме від того, наскільки повно враховуються індивідуальні емоційні особливості та інтереси кожного члена колективу. 